CATALAN REVIEW

Catalan Review

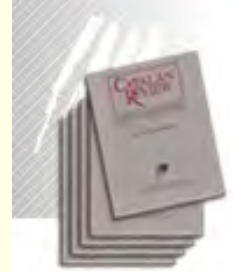

You are accessing the Digital Archive of the Catalan Review Journal.

By accessing and/or using this Digital Archive, you accept and agree to abide by the Terms and Conditions of Use available at http://www.nacs-

catalanstudies.org/catalan review.html

Catalan Review is the premier international scholarly journal devoted to all aspects of Catalan culture. By Catalan culture is understood all manifestations of intellectual and artistic life produced in the Catalan language or in the geographical areas where Catalan is spoken. Catalan Review has been in publication since 1986.
NORTH

AMERICAN

CATALAN

SOCIETY
Esteu accedint a l'Arxiu Digital del Catalan Review

A l' accedir i / o utilitzar aquest Arxiu Digital, vostè accepta i es compromet a complir els termes i condicions d'ús disponibles a http://www.nacs-

catalanstudies.org/catalan review.html

Catalan Review és la primera revista internacional dedicada a tots els aspectes de la cultura catalana. Per la cultura catalana s'entén totes les manifestacions de la vida intel lectual i artística produïda en llengua catalana o en les zones geogràfiques on es parla català. Catalan Review es publica des de 1986.

\title{
Francesc Eiximenis and the Encyclopedic Future: Eiximenis as Prognosticator/on Prognostication Donna M. Rogers
}

Catalan Review, Vol. XX, (2006), p. 329-336 


\title{
FRANCESC EIXIMENIS AND THE ENCYCLOPEDIC FUTURE: EIXIMENIS AS PROGNOSTICATOR/ON PROGNOSTICATION
}

\author{
DONNA M. ROGERS
}

\section{ABSTRACT}

In his vernacular texts, Francesc Eiximenis often ventured to make predictions-sometimes on minor matters, occasionally on the future of entire kingdoms-despite his own uneasiness on the subject of prognostication in general. Despite the apparent contradiction implicit in this behavior, Eiximenis seems to have made a distinction between the concepts of foreknowledge and sorcery, rejecting outright any attempt to use the black art of necromancy to usurp God's divine control over the actions of man.

Francesc Eiximenis, OFM (1327?-1409?), one of the most prolific Catalan writers of the Middle Ages, is known to have composed about a dozen works in the vernacular and in Latin. Eiximenis' Catalan works can be characterized as popularizing theology and lay devotion, while the Latin texts are clerical treatises on sermons and preaching.

Eiximenis' best-known works are the encyclopedic Lo crestià, intended to be a thirteen-volume work on Christian doctrine directed to the lay reader (only four volumes-the Primer, Segon, Terç and Dotzèwere actually completed, although some of the intended content of the other nine is referenced in the extant texts); the Regiment de la cosa pública, a treatise of the Crestiä published separately, with additional material added after Eiximenis' death; the Llibre dels angels; and the Llibre de les dones.

In this essay, I will focus on Eiximenis' treatment of the art of prognostication, often harshly negative; nevertheless, Eiximenis himself was no stranger to attempts at prognostication, and so I will try to reconcile his seemingly opposed stances on the matter in my conclusion.

In the 1920s, Pere Bohigas studied some prophecies and predictions in Catalan texts of the late Middle Ages ("Profecies catalanes"), and subsequently investigated predictions and prophecies found in the works of Eiximenis ("Prediccions"). As David J. Viera has detailed, Bohigas looked at prophecies found in the Primer, Segon, Dotzè, Llibre dels àngels, Vida de Jesucrist, and one of the Latin works, and noted a kind of evolution in Eiximenis' observations: in the Primer, he was concerned mostly with the future of the House of Aragon, while in later 
works he dealt with other royal lines and more general considerations on the state of the world (Viera, Bibliografia 62).

A good many scholars have noted the sometimes astonishing naiveté of Eiximenis in the matter of predictions and prophecies. The most egregious example, and surely the best known, is Eiximenis' prediction in chapter 466 of the Dotzè of the relocation of the Papal See to Jerusalem and the fall of the royal houses of Europe within decades:

Si tu em demanes aquestes presents senyories de christians si duraran fins a la fi del món, respon-te que no ho sé. És ver que alsguns passats han parlat d'aquesta matèria e han posat que aprés la reformació del món, la qual dien que s'ha a fer dins lo centenar present, en què comptam MCCCLXXXV, aprés d'aquest centenar ço dien, se mudarà la seu papal en Jerusalem, e dien que aquí haurà novell papa e novell emperador, e seran abdós de linatge dels jueus convertits a la fe.

[...] Dien encara que, açò fet, tota potestat reial cessarà en lo món, sinó solament en la casa de França, qui durarà longament, per tal car tostemps ha defesa la sancta Església christiana, e ha posat lo papa nou vegades en la cadira papal, gitat d'aquella per enemics de la fe, o per heretges, o per tirans, o per antipapes. E dien que lavors regnarà per tot lo món la justícia popular, que s regirà sots un papa e sots un emperador, fins a la fi del món, així que no hi haurà altre príncep ne rei pus, sinô així com dit és, e cascuna comunitat regirà si mateixa e serà feta pau per toto lo món fins a la fi del món. (Dotze del Crestià, ch. 466; cited in Riquer 2:138)

Not unexpectedly, King Joan I did not respond positively to this prediction, and he wrote to Pere d'Artés in November of 139I:

Entès havem que mestre Francesc Ximenez, qui a vegades s'entremet de l'art de astronomia, pronostica e diu que ans que no passarà l'any de MCCCC, no haurà algun rei de christians al món sinó tan solament rei de França, e que tots los altres realmes de christians, saul aquell, seran comunes, de la qual cosa som fort meravellats que ell vaticín aitals coses, car no s pertanyen de semblant hom tan scient e religiós com ell és, e si no per tal com lo amam e l'havem en nostra afecció, nós hi proveiríem en altra manera. (Rubió, Documents 1:325).

Eiximenis must have answered quickly, distancing himself from the prediction, because Joan wrote directly to him on December I2, 1391:

Jamés no fou intenció nostra ne donam creença que vós semblants coses haguéssets dites ni divulgades, car no ho havets acostumat ne ho requer vostre ordre. (Rubió, Documents 1:372).

But Eiximenis did more: he added several new chapters to the end of Book $\mathrm{t}$ of the Dotzè, stating plainly that the earlier prediction was not to be heeded. In chapter 473 he wrote: 
Tot són fantasies e dits de mal recapte, als quals no deu ésser dada neguna creença. $\mathrm{E}$ per tal los he volguts a mon propòsit posar e encercar en aquest libre, car sé que són molt publicats per lo món e molts los creen així com si era evangeli. Doncs, per tal que negun no hi dó fe ne hi sia enganat, per tal repetesc altra vegada e dic que los dits lurs en lo dit capitol de CCCCLXVI recitats, e ls damunt impugnats, a mon juí no són de neguna creença, ans contenen moltes fatuitats, monçònegues, falsies e oradures. (Dotze del Crestià, ch. 473)

In this way Eiximenis wriggled out of the tight spot his uncritical repetition of the prophecy got him into. Martí de Riquer, recounting this episode, observes that "és força revelador de la mentalitat d'Eiximenis, capaç d'entusiasmar-se ingènuament amb unes absurdes profecies, però amb tan poc convenciment intern que és capaç, també, de contradir-les i desautoritzar-les en les pàgines del mateix llibre" (2:140).

Manuel de Montoliu also notes Eiximenis' “ingènua credulitat” and "manca de sentit crític" with respect to this matter. Indeed, Montoliu applies this criticism more broadly: "en quatre formes d'expressió es reflecteix aquesta enorme credulitat d'Eiximenis: en la seva actitud davant de l'astrologia, davant de l'alquímia, davant del profetisme, i davant les llegendes i les supersticions populars" (33). As we will see, Eiximenis sometimes had difficulty in distinguishing clearly among these.

At around the same time, Eiximenis tells a story in chapter 253 of the Libre de les dones of some Frenchmen praising their king for his good government and liberal rule. Taking exception to this, he characterizes the king as a tyrant and places the following prediction in the mouth of an unnamed Florentine:

Mas espera un poch e veuràs Déus què farà d'ell e de sos grans vassaylls e dels altres princeps qui serven son estil e maneres de viure. Car sàpies que yo sé per persones santes, per qui n só informat, que Déus en breu los portarà a tanta confusió e vergonya e dejecció que no volrien ésser nats, ne fet que fassen notable no prosperarà, ne Déus darà jamés a ells pau mentre aytal vida tinguen. E en breu, los aterrarà tan fort que al món no guosaran apparer.

Then, abandoning the pretext of the anonymous Florentine, Eiximenis himself describes how

lo regne de França con és caegut e vengut despuys a tantes confusions e verguonyes e a tantes dejeccions, les quals no són res a aqueles qui s'i esperen per aquest peccat; ne'ls cal confiar en lo braç ecclesiàstich, car ne aquest porà ajudar a ell, ne ell a ell; e açò per los grans peccats qui regnen de cada part... (Dones 2:370-7r).

This is but one example of many where Eiximenis takes two opposing stances without seeming to be concerned about the contra- 
diction. The publication of two such different predictions about the French monarchy in such a short space of time seems to have posed no problem for Eiximenis himself; he appears to have distanced himself from the prophecy at the end of book I of the Dotzè only because the king was angered.

We find predictions elsewhere in the Libre de les Dones, but typically they are prophecies delivered by angels or ecclesiastics, generally of punishments to be suffered by errant nuns and others who do not heed the word of God. Generally these episodes lay out the predicted punishment in a series of verbs in the future tense, and end with a confirmation that it came true, such as "axís seguí tot de punt en punt" (Dones 1:97) or "dins cinch anys, feta la dita prophecia, tot açò fo complit" (Dones 2:507).

These are examples, then, of Eiximenis trying his own hand at prognostication, and as we have seen he was not very good at it, and in at least one instance got himself into trouble with his royal patron.

I turn now to Eiximenis' observations on the practice of prognostication, which he usually calls necromancy. In chapter 69 of the Primer del Crestià, he relates an anecdote about

Mestre Arnau de Vilanova, qui fon hom il-luminat de diverses ciències, qui menyspreava lo món fort, e anà vestit fort simplement, ne jamés volc prendre muller, e anava tostemps cavalcant en un ase; no havia casa ni alberg; era de la terça regla de Sant Francesc; hom fort famós en saviesa natural, en gran ciència e en virtuosa vida, e hom ab gran zel e fort fervent a incitar tota creatura de servir Déu. Aquest fon en temps del Rei en Jacme d'Aragó, de bona memòria, qui fon frare del Rei Frederic de Sicília. Aquest [=Arnau] sabia l'art de nigromància complidament, e sí fon pregat per lo dit Rei en Jacme que li ensenyàs la dita art, é null temps no la li volc ensenyar, al-legant que mal n'usaria. Emperò, per tal quant amava pus carament lo Rei Frederic de Sicília, atorgà-ho en aquell aprés grans e llongs precs.

E com de fet ell passàs ja en Sicília per aquesta art ensenyar al dit príncep, e vengués en Gènova, aqui li tramès Nostre Senyor Déu malautia qui s'apellava pleuresis. Així com neguna malícia no fos que ell no guarís, aquella emperò no poc guarir, la qual lo empatxava de no ensenyar a negun la dita art. Per què, li ensenyava Déu, e per ell a nós, que no li plaja que ho ensenyàs a negú sens especial inspiració sua. (Primer del Crestià, ch. 69)

We note that here Eiximenis does not criticize Arnau directly; on the contrary, he goes to great lengths to characterize him as "il-luminat," a wise and learned man, and a devout Christian. Nor does he say that necromancy is, per se, wrong. The concern expressed-Arnau's and therefore God's concern-is that Jaume would make bad use of it: "mal n'usaria." That is, in this episode, towards the beginning of the Crestià, necromancy is characterized as an "art" that must be practised 
"complidament." And even when Arnau decided after long consideration to teach it to Frederick, God intervened.

Eiximenis goes into some depth on the subject of prognostication or necromancy in chapter 379 of the Dotzè del crestià (the source for chapter 23 of the Regiment de la cosa pública), "Com deuen esser vedades arts e oficis dampnificants ala comunitat." Together with gambling, corruption and pimping, the regidors are told that

deuen fort esquiuar totes doctrines peccadores e prohibitiues, axi com es nigromancia e totes ses species, axi com geomancia, ciromància e semblants; axi mateix totes arts praues, axi com es art de saber furtar o enganar o tregitar.

E per tal deuen molt esquivar alquimistes, qui comunament son horats $\mathrm{e}$ enganadors e gastadors del seu, e null temps no venen a fi de aço que volen, e vehen-se fondre e perdre. E son axi encarnats en aquella pestilencia, que james no se'n volen llunyar. E per tal com en lo temps present molts homens de qui mal s'o cuidaria hom, se donen a aquesta follia. Sapies per cert que, jatsia que alquimia sia possible, empero Deus, per conservacio de la cosa publica del mon, no la revela sino a fort pocs e a tart, e a aquells qui no entenen en riqueses ne'n profiten molt james a negun, mas solament ne lohen Deu qui tan poderos se mostra en lo orar e en lo amaguar. Contra aquests te do aytal document, que no 1 s crehegues de res que t prometen ne' $t$ diguen. (Dotzèn llibre del crestiä, fol, $26 \mathrm{gv}$; transcription mine)

Up to this point Eiximenis seems to concede the existence of alchemy, at least, but as we will see, right away he condemns it because it leads to necromancy:

Aquesta mala art porta molts a tan leig cas que s fan nigromantichs e servidors del diable. E veies maravella, que hanc nostre Senyor Deu no permes que lo diable pogues reuelar aquesta art, ne permes que lo diable pogues ditar ne enriquehir negu. E pots-ho veure per experiencia, car negun nigromantich hanc per nigromancia no fon rich hom, ne ajusta a res, ans a la fi pert si mateix e tot quant ha. . (Dotzèn llibre del crestiä, fol. 26gv; transcription mine)

So he has condemned all the "depraved arts," such as necromancy and chiromancy, associating them with theft and deception. He then makes this connection explicit, condemning both alchemy and astrology as diabolical arts that inevitably lead to necromancy. $\mathrm{He}$ observes that the prognosticators are unskilled at revealing the future, since they cannot foresee their own bad end. Most importantly, however, the prognosticator usurps the divine right of God alone to know-indeed, to determine-what is to come:

Per que consellaren los antichs que, per tal que negu vingues a aquesta tan lega art, que negu no's entrameses pregonament de astrologia ne de alquimia, car aquestes dos sçiences eren gran disposicio a caure en aquesta mala art de 
nigromancia. E cascuna axi mateix de ses species deu hom esquivar axi com a vies de mort, car totes son species de diuinar, la qual cosa se pertany solament a Deu. [...] Quaix que digua que adeuinar, ne pronosticar ne jugar [jutjar] ans de temps de les coses contingents é esdeuenidores, ne dir de cert 'axi sera o axi no sera, en aytal materia solament se pertany a nostre Senyor Deus. E per tal aquell tol a Deu les sues regalies quant en si es e comet crim de lesa maiestat en lo princep general, qui es totpoderos Deu, qui per aytals arts defeneix de les coses contingents esdeuenidores e amaguades. E per ço veuras per experiencia que aytals homens venen a mala fi. E jarsia que als altres se facen adeuinadors, empero a ssi mateixs no saben adeuinar la mala fi a que venen. . (Dotzèn llibre del crestià, fols. $269 \mathrm{v}-270 \mathrm{~g}$; transcription mine)

\section{This section ends with a curious personal observation:}

Yo viu vna veguada un dels grans nigromantichs del mon, empero no sabe a ssi mateix preueure son mal, car negua en la mar en la plaga de Barcelona. (Dotzèn llibre del crestià, fol. 27or; transcription mine)

Among Eiximenis' frequently consulted sources were Augustine's De civitate dei, John of Salisbury's Policraticus, and Hugh of St. Victor's Didascalicon, all of which condemned necromancy, divination, and magic in all forms (Peters 6, 46-50, 53, 56, 65-66, 70, 127). The latter of these directly linked the heretic and the magician, and sometimes this led to an explicit association of the occult with the Jews (Peters I213). Eiximenis himself makes this connection more than once: in the Primer he observes that

Ocasió de malícia judaica és estada o pot ésser estada influència celestial [...] Posa Tolomeu en el segon llibre del seu quadripartit e en lo quart capitol, que la terra o habitació que solia ésser llavors dels jueus rep éspecial influència d'aquella planeta que s'apella Saturno, e sa influència malencònica, maliciosa, freda, seca, nocturnal e poderosa ha influència de qualitats mortals. (Primer del Crestia, cited in Montoliu 34)

At the end of chapter 379 of the Dotzè, as he summarizes his arguments against necromancy and prognostication, he reminds us that

los regents de la cosa publica deuen axi com dit es esquiuar aquestes arts pestilents e perseguir e foragitar de llurs comunitats a tots aquells que les ensenyen e aquells qui $n$ husen, per poch que n sien tocats. E deu-los-hi moure en special zel de la reverençia diuinal, car com dit es, aquests notablement presumexen cometre crim contra la diuinal maiestat, o son ja en la via de cometre, de la qual cosa se segueix souint la divinal yra contra la comunitat. . (Dotzèn llibre del crestiä, fol. 27or; transcription mine)

This is followed immediately by a Biblical reference (Joshua 7) that Eiximenis tells us demonstrates the presumption of certain Jews in questioning the will of God: 
la comunitat judayca fo axi dampnificada e enuergonyida e vençuda, e per Deu desemparada, quant mes es. Deus prouocat a hira contra aquella comunitat qui soste scientment aquells que viuen ab tanta irreuerencia de Deu e qui li fa tanta de deshonor, que cometen manifesta ydolatria en terra de chrestians. . (Dotzèn llibre del crestià, fol. 27ov; transcription mine)

In the broader context of beliefs about prognostication, magic and the occult in the European Middle Ages, Eiximenis' inconsistencies should not surprise us too much. There was for centuries an uncomfortable, slippery truce between acceptable Christian practices of divinely assisted prophecy (via angels and holy men and women, for instance), as well as acceptable Christian supernatural phenomena (that is, miracles), and "illegitimate" knowledge: heresy, magic, witchcraft, necromancy, etc. In his 2003 edition of the Tractat de prenostication, John Lucas gives an excellent, thorough overview of prognostication and magic in Europe-and specifically in Catalonia-through the Middle Ages and Renaissance, and this unease is clear to see.

In the end, for Eiximenis, the sliding scale of acceptibility lies in the distinction between prognostication as foreknowledge and as sorcery. He seems to accept the former to some slight degree (as in the tale about Arnau de Vilanova, a man he clearly respected), but rejects out of hand any use of this art that can be construed as appropriation of the divine knowledge that belongs only to God.

DONNA M. ROGERS DALHOUSIE UNIVERSITY

\section{WORKS CITED}

BoHIGas, Pere. "Profecies catalanes dels segles XIV i xv." Butlleti de la Biblioteca de Catalunya 6 (1920-22): 35-37.

- "Prediccions i profecies en les obres de Fra Francesc Eiximenis." Franciscalia. Barcelona: Editorial Franciscana, 1928. 23-38.

Eiximenis, Francesc. Primer del Crestià. Valencia: Lambert Palmart, 1483.

- Dotzèn llibre del Crestiä. Ms. Esp. 9. Bibliothèque National, Paris.

- Dotzè llibre del Crestiä. Vol. I, pt. ı. Girona: Publicacions de l'Universitat de Girona, 2006.

- Dotzè llibre del Crestià. Vol. II, pt. I. Girona: Col-legi Universitari de Girona, 1986.

-. Lo Crestià (Selecció). Ed. Albert Hauf. Barcelona: Edicions 62 i "La Caixa," 1983. 
-. Lo libre de les dones. Ed. Frank Naccarato. Revised by Curt J. Wittlin and Antoni Comas. 2 vols. Barcelona: Curial Edicions Catalanes, 198I.

LUCAS, John Scott. Astrology and Numerology in Medieval and Early Modern Catalonia: The Tractat de prenostication de la vida natural dels homens. The Medieval and Early Modern Iberian World, I8. Leiden and Boston: Brill, 2003.

MONTOLIU, Manuel de. Eiximenis, Turmeda i l'inici de l'bumanisme a Catalunya: Bernat Metge. Barcelona: Alpha, 1959.

PETERS, Edward. The Magician, the Witch and the Law. Philadelphia: U of Pennsylvania P, 1978.

RiQuer, Martí de. Història de la literatura catalana. Vol. 2. Barcelona, Ariel, 1964.

RUBiO I LlUCH, Antoni. Documents per l'bistòria de la cultura catalana mig-eval. 2 vols. Barcelona, Institut d'Estudis Catalans, 1908$2 I$.

VIERA, David J. Bibliografia anotada de la vida $i$ obra de Francesc Eiximenis (1340?-1409?). Barcelona: Fundació Salvador Vives Casajuana, 1980.

-. Medieval Catalan Literature: Prose and Drama. Boston: Twayne, I988. 